\section{Acute renal failure after eating raw fish gall bladder}

Various fishes are poisonous, the most commonly recognised being ciguatera and scombroid poisoning. ${ }^{1}$ The raw gall bladder of the grass carp (Ctenopharyngodon idellus) has both nephrotoxic and hepatotoxic properties, which are less known.

\section{Case reports}

Case 1-A 37 year old housewife ate the raw gall bladder of a grass carp and six hours later had central colicky abdominal pain, vomiting, and watery diarrhoea for several hours. She was admitted to hospital three days later because of oliguria. Physical examination showed nothing abnormal except for jaundice. There was no dehydration. Results of investigations were: serum urea concentration $37.5 \mathrm{mmol} / 1(226 \mathrm{mg} / 100 \mathrm{ml})$, creatinine $1350 \mu \mathrm{mol} / 1(15.3 \mathrm{mg} / 100 \mathrm{ml})$, bilirubin $75 \mu \mathrm{mol} / 1(4.4 \mathrm{mg} / 100 \mathrm{ml}$ ) (direct $56 \mu \mathrm{mol} / 1 ; 3.3 \mathrm{mg} / 100 \mathrm{ml}$ ), aspartate aminotransferase (AST) activity $114 \mu \mathrm{mol} / \mathrm{min} / 1$ (normal 8-32), alanine aminotransferase (ALT) activity 1178 $\mu \mathrm{mol} / \mathrm{min} / \mathrm{l}$ (normal 3-34). Total urine output was below $500 \mathrm{ml}$ for seven days but gradually increased to $1200 \mathrm{ml}$ by the twelfth day, reaching $4750 \mathrm{ml}$ on the fourteenth day. Her serum creatinine concentration peaked on the tenth day and then improved. Dialysis was not performed. AST activity decreased to $43 \mu \mathrm{mol} / \mathrm{min} / \mathrm{l}$ and ALT activity to $180 \mu \mathrm{mol} / \mathrm{min} / \mathrm{l}$ after threc days (table). Renal biopsy at four weeks showed evidence of recent interstitial oedema with interstitial fibrosis and features of acute tubular necrosis with regeneration. Immunofluorescence results for $\operatorname{IgG}, \operatorname{IgM}, \operatorname{IgA}$, and fibrin were negative. Both renal and liver function returned to normal on discharge.

Case 2-A 32 year old man was admitted because of central abdominal pain with vomiting and watery diarrhoea five hours after eating the raw gall bladder of a grass carp. Physical examination showed nothing abnormal. On admission the serum urea concentration was $5.4 \mathrm{mmol} / \mathrm{l}(32.5 \mathrm{mg} / 100 \mathrm{ml})$, creatinine concentration $60 \mu \mathrm{mol} / 1(0.7 \mathrm{mg} / 100 \mathrm{ml})$, AST activity 12330 $\mu \mathrm{mol} / \mathrm{min} / 1$ (normal $11-35$ ) and ALT activity $5730 \mu \mathrm{mol} / \mathrm{min} / 1$ (normal 5-48) After admission his urine output decreased and he became anuric with a serum urea concentration rising to $34.5 \mathrm{mmol} / 1(208 \mathrm{mg} / 100 \mathrm{ml})$ on the third day. Haemodialysis was performed. Diuresis occurred 17 days later, after a total of eight sessions of haemodialysis, and renal function gradually returned to normal. Liver function improved spontaneously, AST activity falling to $53 \mu \mathrm{mol} / \mathrm{min} / 1$ and ALT activity falling to 1060 $\mu \mathrm{mol} / \mathrm{min} / \mathrm{l}$ on the third day (table). Renal biopsy showed acute tubula necrosis with swelling and degeneration of epithelial cells, mainly of the proximal convoluted tubules.

Laboratory and clinical findings in the three patients

\begin{tabular}{|c|c|c|c|}
\hline & Case 1 & Case 2 & Case 3 \\
\hline $\begin{array}{l}\text { Red blood cell count/high power } \\
\text { field }\end{array}$ & 一 & 一 & $8-10$ \\
\hline $\begin{array}{l}\text { White blood cell count/high power } \\
\text { field }\end{array}$ & $5-6$ & $10-20$ & $2-8$ \\
\hline Casts & - & Epithelial + & Granular + \\
\hline Bilirubin & Negative & Negative & Negative \\
\hline Urobilinogen & Not raised & Not raised & Not raised \\
\hline 24 hour urinary protein $(\mathrm{g})$ & $0 \cdot 12$ & $0 \cdot 18$ & $0.19,0.3$ \\
\hline Maximum blood urea $(\mathrm{mmol} / \mathrm{l})$ & $36 \cdot 4$ & 34.5 & $25 \cdot 9$ \\
\hline$\underset{(\mu \mathrm{mol} / \mathrm{l})}{\text { Maximum serum creatinine }}$ & 1850 & 1930 & 964 \\
\hline $\begin{array}{l}\text { AST on admission and } 3 \text { days } \\
\text { later }(\mu \mathrm{mol} / \mathrm{min} / \mathrm{l})\end{array}$ & 114,43 & 12330,53 & 7380,17 \\
\hline $\begin{array}{l}\text { ALT on admission and } 3 \text { days } \\
\text { later }(u \mathrm{~mol} / \mathrm{min} / \mathrm{l})\end{array}$ & 1178,180 & 5730,1060 & 5130,478 \\
\hline Time to onset of symptoms (hours) & 6 & 5 & 18 \\
\hline $\begin{array}{l}\text { Time to onset of oliguria/anuria } \\
\text { (hours) }\end{array}$ & 48 & 72 & - \\
\hline Time to onset of diuresis (days) & 14 & 17 & - \\
\hline
\end{tabular}

Conversion: SI to traditional units-Blood urea: $1 \mathrm{mmol} / 1 \approx 6 \mathrm{mg} / 100 \mathrm{ml}$. Serum creatinine: $1 \mu \mathrm{mol} / 1=0.01 \mathrm{mg} / 100 \mathrm{ml}$. AST: $1 \mu \mathrm{mol} / \mathrm{min} / 1=1 \mathrm{IU} / 1$. ALT: $1 \mathrm{kmol}$ $\min / 1=1$ IU

Case 3-A 53 year old housewife was admitted complaining of dizziness preceded by flushing 18 hours after eating part of the raw gall bladder of a grass carp. There was no gastrointestinal upset. Physical examination showed no abnormality. Her symptoms subsided spontaneously after admission. On admission her serum urea concentration was $6.4 \mathrm{mmol}$ $(38.6 \mathrm{mg} / 100 \mathrm{ml})$ and creatinine concentration $118 \mu \mathrm{mol} / 1(1.3 \mathrm{mg} / 100 \mathrm{ml})$ but these rose to peak values of $25.9 \mathrm{mmol} / 1(156 \mathrm{mg} / 100 \mathrm{ml})$ and $964 \mu \mathrm{mol} /$ $(10.9 \mathrm{mg} / 100 \mathrm{ml})$ respectively after five days. The patient, however, continued to have a daily urine output of $1500-2000 \mathrm{ml}$. Renal function returned to normal in three weeks. Liver function also showed improvement, AST activity decreasing from 7380 to $17 \mu \mathrm{mol} / \mathrm{min} / 1$ and ALT activity decreasing from 5130 to $478 \mu \mathrm{mol} / \mathrm{min} / 1$ after three days (table). Muscle enzyme activities (creatinine phosphokinase $39 \mu \mathrm{mol} / \mathrm{min} / 1$ and lactate dehydrogenase 230 $\mu \mathrm{mol} / \mathrm{min} / \mathrm{l}$ were normal.

\section{Comment}

The freshwater grass carp is commonly eaten in Asia. Swallowing its gall bladder raw is believed by some to be good for health, especially for rheumatism, and our patients did so for this reason. Cases of toxicity after eating raw gall bladder of grass carps have been reported only sporadically..$^{2-4}$ All except one patient (our case 3 ) presented initially with gastrointestinal upset including abdominal pain, nausea, vomiting, and watery diarrhoea several hours after ingestion. In all patients hepatotoxicity and nephrotoxicity occurred. The hepatitic picture, observed within hours of ingestion, was attributed to hepatotoxins rather than to an infective agent in the raw bile. ${ }^{2}$ The putative toxin has not been identified; nevertheless, that such a toxin exists is supported by the fact that boiled raw bile of the grass carp is toxic in animals. ${ }^{5}$ This implies possible toxicity of cooked fish gall bladders, although no case has been reported.

Spontaneous resolution of hepatic dysfunction within a few days is usual. More serious is the nephrotoxicity, which culminates in either the oliguric or the non-oliguric form of acute renal failure, usually within 48-72 hours after ingestion while hepatic dysfunction is resolving. The biopsy findings of acute tubular necrosis are similar to that produced by other common nephrotoxins. In the one patient (case 3 ) in whom muscle enzyme activities were measured no evidence of rhabdomyolysis was obtained.

Our report should help alert physicians to such a possible but rare cause of acute renal failure.

Anonymous. Fish poisoning. Br Med f 1980;281:890.

Chen WY. Acute renal failure due to ingestion of raw bile of grass carp (Ctenopharyngodon idellus). Taiwan I Hsuch Hui Tsa Chih 1976;75:149-57.

3 Chan MK. Fish gallbladder poisoning: report of case. Modern Medicine of Asia

4 Chen WY. Acute renal failure due to raw bile of grass carp. 7 Med Assoc Thai 1978;61:63-70.

5 Yip LL. Toxic material from the gall-bladder of the grass carp (Ctenopharyngodon idellus). Toxicon 1981;19:567-9.

(Accepted 20 December 1984)

Department of Medicine, University of Hong Kong, Queen Mary Hospital, Hong Kong

D W S CHAN, MB, BS, medical officer

C K YEUNG, MB, FRACP, senior lecturer

$M$ K CHAN, MD, MRCP, reader

Correspondence and requests for reprints to: Dr Diana W S Chan.

\section{Respiratory arrest after solvent abuse}

Roughly 80 deaths each year in the United Kingdom are associated with solvent abuse. ${ }^{1}$ In about half the cases death is attributed to cardiac arrhythmias, a direct central nervous depressant effect, asphyxia, and hepatorenal failure. ${ }^{2}$ Most cases of sudden death are thought to be caused by cardiac sensitisation with resultant ventricular fibrillation linked with hypercapnia, stress, or activity. ${ }^{3}$ Nevertheless, most deaths associated with solvent abuse occur outside hospital and the exact mechanism of sudden death is still not clear. Asphyxia has been proposed in cases where no other cause was found or seemed likely. ${ }^{2}$ We report a case of reversible respiratory arrest after acute inhalation of adhesive containing toluene.

\section{Case report}

A previously fit 21 year old punk rocker was admitted to the casualty department after a six hour glue sniffing session, which resulted in severe behavioural disturbance. On the way to hospital by ambulance his level of consciousness deteriorated and respiration stopped for about two minutes. $\mathrm{He}$ was resuscitated with an airway and Ambu bag and spontaneous respiration restarted. On admission to the casualty department he was breathing normally with an airway in situ. He was drowsy, but had no focal neurological signs and normal sized pupils. He suffered a further respiratory arrest (again lasting about two minutes) while in the casualty department. His electrocardiogram, which was monitored continuously during this period of apnoea, showed sinus tachycardia only. He was resuscitated again with an Ambu bag and after an attempt at intubation began breathing spontaneously. He quickly regained full consciousness and made an uneventful recovery over the succeeding 24 hours. He was given no drugs. 
He later gave a six year history of heavy solvent abuse (four litres of Evostick per week, which he inhaled from a plastic bag). He denied intravenous drug abuse and the consumption of any drugs or alcohol on the day of admission. Urine screen for toluene breakdown products was strongly positive (urine hippuric acid concentration $=2.5 \mathrm{~g} / 1$ : normal range $0 \cdot 1-0 \cdot 2$ $\mathrm{g} / \mathrm{l}$ ). A complete drug screen was otherwise negative. The results of routine blood tests and chest $x$ ray examination were normal.

\section{Comment}

Considerable emphasis has been placed on cardiac arrhythmias as the major cause of sudden death in solvent abuse. We believe that reversible respiratory arrest, despite a normal electrocardiogram, has not been reported. Nevertheless, respiratory depression in solvent abusers might be expected, since studies in animals have shown that toxic concentrations for the central nervous system and cardiac sensitisation are similar. Depression of central nervous system function by solvents probably occurs in a similar manner to the depressant effects of most general anaesthetic agents. Central nervous system toxicity in rats evolved from tremor to narcosis, followed by shallow respiration and death from respiratory depression. Death was inevitable above a critical toxic concentration. ${ }^{4}$ For this reason patients who lose consciousness during or after solvent abuse should be closely monitored.

We believe that this case report supports the theory that respiratory depression alone may be an important cause of sudden death in solvent abusers. There may be no distinctive features at necropsy suggestive of the mode of death, and this probably accounts for the rarity of respiratory depression as a postmortem diagnosis in solvent abusers.

We thank Dr L W Loughridge for permission to report this case, and Miss Emma Clark and Mrs Anita Aydassen for secretarial help.

1 Ande :son HR, Macnair RS, Ramsey JD. Epidemiology: Deaths from abuse of volatile substances: a national epidemiological study. Br Med F 1985;290:304-7. 2 Anderson HR, Dick B, Macnair RS, Palmer JC, Ramsey JD. An investigation of 140 deaths associated with volatile substance abuse in the United Kingdom. Hum Toxicol 1982;1:207-21.

3 Bass M. Sudden sniffing death. FAMA 1970;212:2075-9. Clark DG, Tinston DJ. Acute inhalation toxicity of some halogenated and non-
halogenated hydrocarbons. Hum Toxicol $1982 ; 1: 239-47$.

(Accepted 13 December 1984)

\section{Medical Unit, Westminster Hospital, London SW1P 2AP}

$S$ L CRONK, MB, house officer

D E H BARKLEY, BSC, MB, senior house officer

M F FARRELL, MB, MRCP, registrar

Correspondence to: Dr D Barkley, Brompton Hospital, London SW3.

\section{Pregnancy after chemotherapy induced ovarian failure}

Several groups have studied reproductive function after MVPP (mustine, vinblastine, procarbazine, and prednisolone) or MOPP (mustine, vincristine, procarbazine, and prednisolone) chemotherapy for Hodgkin's disease, and the incidence of amenorrhoea has ranged from $15 \%$ to $62 \% 0^{1-4}$ The cessation of menses is related to age and is accompanied by an increase of serum gonadotrophin concentrations and a decreased serum oestradiol value consistent with primary ovarian failure. Apart from age, there have been no clear differences noted between those women who become amenorrhoeic and those who do not. Schilsky et al, in their long term follow up of ovarian function in women treated with quadruple chemotherapy for Hodgkin's disease, concluded that if premature ovarian failure developed, then it was invariably permanent. We describe a patient in whom amenorrhoea was not permanent and in whom pregnancy occurred only because she disregarded the advice of her doctors concerning sex steroid replacement therapy.

\section{Case history}

In June 1978 a 23 year old woman presented with cervical lymphadenopathy and an enlarged liver and spleen. Histologically a biopsy sample of lymph node showed nodular sclerosing Hodgkin's disease. Between July 1978 and May 1979 she received eight courses of quadruple chemotherapy with MVPP. Subsequently she remained well and required no further treatment for Hodgkin's disease.

Up until early 1981 she had taken the oral contraceptive pill but this was stopped as she was interested in the possibility of fertility. By January 1982 she had seen only one period in the past nine months. Serum follicle stimulating hormone and luteinising hormone concentrations ( $>32$ IU / $)$ and serum oestradiol concentration $(104 \mathrm{pmol} / 1 ; 28 \mathrm{pg} / \mathrm{ml})$ were consistent with primary ovarian failure. She was advised that the cause of her amenorrhoea was chemotherapy induced ovarian failure and that she required sex steroid replacement therapy. Treatment with ethinyloestradiol-levonorgestrel (Microgynon 30) was begun but she remained concerned about her chances of fertility. Thus in order to provide further information about her fertility prospects a laparoscopy and ovarian biopsy were performed in March 1983. The biopsy samples showed complete absence of ovarian follicles and she was advised to continue with Microgynon 30. She did not take her sex steroid replacement therapy. Between July and December 1983 she had five normal periods, and in January 1984 the progesterone concentration on day 21 was consistent with ovulation. In February pregnancy was confirmed, and at the end of September she delivered a healthy baby boy weighing $3400 \mathrm{~g}$.

\section{Comment}

This young woman showed clinical and biochemical features of primary ovarian failure as a result of quadruple chemotherapy for Hodgkin's disease. The amenorrhoea was thought to be permanent in the light of the ovarian biopsy findings and the "known" course of chemotherapy induced ovarian failure. ${ }^{3}$

In young women with ovarian failure sex steroid replacement therapy is advised to prevent dyspareunia, loss of libido, and the risk of osteoporosis. During treatment it is impossible to determine if the ovarian failure is reversible and, of course, infertility is permanent.

Our patient's history indicates that cytotoxic induced ovarian failure may be reversible, and this poses a therapeutic dilemma in patients similarly treated who wish to conceive. It may be argued that we were unwise to assume an absence of residual primordial follicles from an ovarian biopsy sample obtained at laparoscopy. ${ }^{5}$ Thus to ensure that enough ovarian material has been obtained for adequate histological evaluation, laparotomy and ovarian wedge resection may be required in some of these young women; these procedures, however, are not without their own complications. ${ }^{5}$ Under similar circumstances, if an otherwise asymptomatic young woman who is desirous of a pregnancy prefers not to undergo a laparotomy and ovarian wedge resection she may choose not to take sex steroid replacement therapy despite the increased risk of osteoporosis.

The reproductive history of this patient illustrates that it is unwise to assume that amenorrhoea and infertility are inevitably permanent after chemotherapy induced ovarian damage.

\section{Chapman RM, Sutcliffe SB, Malpas JS. Cytotoxic-induced ovarian failure in women with Hodgkin's disease. $\mathcal{F} A M A$ 1979;242:1877-81. 2 Horning SJ, Hoppe RT, Kaplan HS, Rosenberg SA. Female reproductive potential \\ 3 Schilsky RL, Sherins RJ, Hubbard SM, Wesley MN, Young RC, DeVita VT Lengterm follow-up of ovarian function in women treated with MOPP chemo- therapy for Hodgkin's disease. Am $\mathcal{f}$ Med 1981;71:552-6. \\ 4 Whitehead E, Shalet SM, Blackledge G, Todd I, Crowther D, Beardwell CG The effect of combination chemotherapy on ovarian function in women treated for Hodgkin's disease. Cancer 1983;52:988-93. \\ 5 Maxson WS, Wentz AC. The gonadotropin resistant ovary syndrome. Seminars in Reproductive Endocrinology 1983;1:147-60.}

(Accepted 20 December 1984)

\section{Christie and Withington Hospitals, Manchester}

S M SHALET, MD, FRCP, consultant physician and endocrinologist

C A VAUGHAN WILLIAMS, MD, MRCOG, lecturer in obstetrics and gynaecology

E WHITEHEAD, MB, MRCP, research fellow in endocrinology

Correspondence to: Dr S M Shalet, Department of Endocrinology, Christie Hospital and Holt Radium Institute, Manchester M20 9BX.

\section{Correction}

\section{Blood group as a prognostic indicator in breast cancer}

In the results section, third paragraph, third line, and in table III of the article by $\mathrm{P}$ J Holdsworth et al, published on 2 March (p 671) "M stage" should read "N stage." 